\title{
William Faulkner'ın Sanctuary romanının Türkçede nasıl adlandırıldığı üzerine betimleyici bir çalışma ${ }^{1}$
}

\section{Gülsüm CANLI²}

Ayşe Banu KARADAĞ3

\begin{abstract}
APA: Canlı, G.; Karadă̆, A. B. (2019). William Faulkner'ın Sanctuary romanının Türkçede nasıl adlandırıldığı üzerine betimleyici bir çalışma. RumeliDE Dil ve Edebiyat Araştırmaları Dergisi, (14), 454-468. DOI: $10.29000 /$ rumelide.541084
\end{abstract}

\section{$\ddot{O} \mathbf{z}$}

Türk okuru, Nobel ödüllü Amerikalı yazar William Faulkner'ı (1897-1962), 1950’li yıllarda tanır. Aradan geçen sürede yaklaşık yirmi eserinin Türkçeye çevrildiği düşünülecek olursa, yazarın günümüz Türk edebiyat ve kültür dizgesinde önemli bir yer edindiği söylenebilir. Türkçeye çevrilen Faulkner eserleri arasında, Sanctuary (1931) romanı, toplamda üç çevirisi olan tek Faulkner metni olması sebebiyle özellikle dikkat çeker. Roman ilk olarak 1961 yılında Kutsal Sığınak adıyla Ender Gürol tarafından çevrilmiştir. Sonraki çevirilerse sırayla 1967 yılında Özay Sunar tarafından Lekeli Günler ve 2007 yılında Necla Aytür tarafından Tapınak adıyla yapılmıştır. Görüldüğü üzere romanın adı her çeviride farklı yorumlanmış ve eser Türkçeye üç farklı adla kazandırılmıştır. Bu çalışmanın amacı, Faulkner'ın Sanctuary romanının Türkçeye yapılan üç farklı çevirisinin neden farklı adlarla yapıldığının gerekçelerini betimleyici bir yaklaşımla irdelemektir. Edebiyat eserlerinin adlandırılmasına dair yapılan çalışmalarda tartışmalar, metinlerin nasıl adlandırılacağı, metin ve ad arasındaki ilişki, metin adlarının işlevleri gibi konuları ele almaktadır. Bahsi geçen konular, sadece telif eserlerin adlandırılması ile sınırlı kalmamış, çeviri eserlerin adlandırılması bağlamında da tartışılmıştır. Örneğin, “Titles and Translation” başlıklı çalışmasında çevirilerin nasıl adlandırılacağına dair görüşlerini paylaşan Maurizio Viezzi, çevirilerin adlandırılmasının masum olmadığını iddia eder (2013: 383). Bu iddiadan hareketle, çalışma kapsamında, Sanctuary romanının Türkçeye yapılan çevirilerine verilen adların gerekçeleri, metin içi ve metin dışı ögelerle incelenecektir.

Anahtar kelimeler: Çeviri adlarının karşılaştırmalı çözümlemesi, edebî çeviri, Sanctuary.

\section{A descriptive study on the Turkish titles of William Faulkner's Sanctuary}

\begin{abstract}
Turkish readers met Nobel Laureate, American author William Faulkner (1897-1962) for the first time in 1950s. Considering the fact that about twenty of Faulkner's works have been translated so far, it is now possible to say that Faulkner has gained an important place in today's Turkish literature. Among his translated works, the novel Sanctuary (1931) attracts more attention as the only Faulkner novel with three Turkish translations. The novel was translated into Turkish for the first time in 1961

\footnotetext{
$1 \quad$ Bu makale Öğg. Gör. Gülsüm Canlı’nın Prof. Dr. Ayşe Banu Karadağ’’n danışmanlığında hazırladığı “William Faulkner’ın Sanctuary Adlı Romanının Kaynak ve Erek Dizgedeki Çeviri Serüveni: Diliçi Çeviri, Öz-çeviri, Yeniden Çeviri ve Dolaylı Çeviri Kavramları Işı̆̆ında Bir Inceleme” başlıklı doktora tezinden üretilmiştir (Yıldız Teknik Üniversitesi, Sosyal Bilimler Enstitüsü, Diller ve Kültürlerarası Çeviribilim Doktora Programı).

2 Öğr. Gör., İstanbul Üniversitesi, Yabancı Diller Yüksekokulu, (İstanbul, Türkiye), canligulsum@gmail.com, ORCID ID: oooo-0001-6720-1147 [Makale kaylt tarihi: 26.02.2019-kabul tarihi: 14.03.2019; DOI: 10.2900o/rumelide.541084] Prof. Dr., Yıldız Teknik Üniversitesi, Fen Edebiyat Fakültesi, Batı Dilleri ve Edebiyatı Bölümü, Mütercim-Tercümanlık
} (Fransizca), (İstanbul, Türkiye), akaradag@yildiz.edu.tr, ORCID ID: 0000-0002-0974-8053
\end{abstract}


as Kutsal Siğınak by Ender Gürol. The following translations were rendered in 1967 as Lekeli Günler by Özay Sunar, and in 2007 as Taprnak by Necla Aytür. Apparently, the title of the novel has been interpreted differently with each translation. With a descriptive approach, this paper aims to analyze why Faulkner's novel Sanctuary (1931), which has been translated into Turkish three times, has been translated with a different title by each translator. There are various studies on the titles of literary works which discuss issues such as how to determine the title of a text, the relation between a text and its title, and the functions of titles. Similar issues are discussed also within the scope of translated titles. For example, in the article "Titles and Translation", Maurizio Viezzi discusses how to translate titles and claims that "title translation is not innocent" (2013: 383). Taking this claim into consideration, this study aims to analyze the motives behind the translated titles of Sanctuary via intra-textual and extra-textual materials.

Key words: Comparative analysis of translated titles, literary translation, Sanctuary.

\section{Giriş}

Metinle okur arasındaki ilk bağ olması sebebiyle bir kitabın adının büyük önem taşıdığı söylenebilir. Kapaktaki adın çoğu zaman kitaba dair bilgi barındırdığı düşünülür. Bu nedenle, herhangi bir metne verilen adın, önce okuma kararının alınmasında, sonrasındaysa okunan metnin algılanışında etkin bir rol üstlendiği iddia edilebilir.

Bu konu, bilimsel çevrelerde hem edebiyat alanında, hem de çevribilim alanında farklı şekillerde ele alınmıştır. Örneğin metne verilen adın metnin algılanmasındaki rolü üzerine yaptıkları bir deneyle Gillian Brown ve George Yule, metin ve ad ilişkiselliğine dair ilginç sonuçlar elde etmiştir. Deney kapsamında bir paragrafa 'A Prisoner Plans his Escape' ve 'A Wrestler in a Tight Corner' şeklinde iki farklı ad yazılır ve iki deney grubuna aynı metin farklı adlarla okutulur. Katılımcılardan çeşitli sorulara cevap vermeleri istenir. Sorulara verilen cevapların metnin adına göre şekillendiği gözlemlenir. Birinci grup okuduğu metnin, hapiste olmaktan hiç memnun olmayan bir tutukluyu, ikinci grupsa içinde bulunduğu zor durumdan çıkıp özgür kalmaya çabalayan bir güreşçiyi anlattığını düşünür (Brown \& Yule, 1983: 139-140). Bahsi geçen deneyin, okur tarafından metnin adına yüklenen bağlamsal önemi gözler önüne serdiği söylenebilir. Deneyin sonuçlarından hareketle, okur açısından bakıldığında metin adları tekil değil bağlamsal birimlerdir.

Küçük bir metinsel birim olan paragraf ve ad arasındaki bağlamsal ilişkinin, söz konusu bir film, masal, hikâye ya da roman olduğunda da geçerliliğini ve etkisini devam ettirdiğini söylemek mümkündür. Ayrıca, bir eserin alımlanışının başlangıç noktası olan eser adları, sadece telifte değil çeviride de büyük önem taşır. Yazılı ya da görsel herhangi bir metin, bir çeviri süreciyle erek kültür bağlamına taşınırken, çevirmen ve/veya editör, adın çevirisinde alacağı bir kararla, esere dair oluşacak ilk izlenimi ciddi ölçüde şekillendirebilir. Üstelik metnin adına dair alınan çeviri kararının, metin içi çeviri kararlarına da yansıması ve çevrilen metnin bütüncesini etkilemesi de mümkündür. Dolayısıyla söz konusu hikâye, roman gibi yazılı bir metinse okuma, film gibi görsel bir metinse izleme eylemi aslında en baştan çevirmenin ve/veya editörün etkisiyle belli bir doğrultuda yönlendirilebilir. Hem telifte hem de çeviride bu kadar önem taşırken metnin adlandırılmasının rastlantısal olmasını beklemek çok da olası görünmemektedir.

Bu çalışmanın inceleme nesnesi olan Sanctuary özelinde metin ve ad arasındaki ilişkiye bakıldığında ilginç bir nokta dikkat çeker. Paratexts: Thresholds of Interpretation (Literature, Culture, Theory) 
(1997) adlı kitabında Gérard Genette'in, William Faulkner'ın Sanctuary romanını 'mecazi anlamda kullanılan simgesel adlar' kategorisinde ele almış olduğu gözlemlenir (1997: 82). Dikkat çeken bir diğer nokta ise romanın adının kaynak dizgede de çeşitli tartışmaları beraberinde getirmiş olmasıdır (Krş. Urgo, 1983 \& McDonald, 1997). Ayrıntılarına ilerleyen bölümlerde değinilecek olan bu tartışmaların ve Genette'in kategorilendirmesinin kaynak metnin adıyla metin arasındaki bağı anlamaya yardımcı olduğu düşünülmektedir. Sanctuary özelinde kaynak dizgede yapılan bu çalışmalar, Türk erek dizgesinde ise çevirilerin nasıl ve neden Kutsal Siğınak, Lekeli Günler ve Tapınak şeklinde adlandırıldığına dair tartışmaların önünü açmaktadır.

Türkçeye yapılan çevirilere verilen adlar ilk ve son çeviri özelinde, ilk bakışta akla kaynak metnin adının sözlükteki karşıllğını getirmektedir. Sözlükte ‘sanctuary' için verilen tanımlar şu şekildedir:

1. a sacred place, eg a church, temple or mosque

2. a) a place where sb is protected from people wishing to arrest or attack them b) such protection

3. an area where birds and wild animals are protected and encouraged to breed (Hornby, 1995: 1040).

Birinci erek metnin, ilk iki maddedeki ifadeleri birleştirerek Kutsal Siğınak şeklinde bir adlandırmaya gittiği söylenebilir. İlk maddedeki 'sacred place' (kutsal mekân) açıklamasından alınan kutsallık ile, ikinci maddedeki 'a place where sb is protected from people wishing to arrest or attack them' (kişinin kendisine saldırmak isteyen insanlardan korunduğu mekân) açıklamasından alınan korunma, sığınma vurgusu birleştirilmiş ve böylece metnin adına son hâli verilmiş olabilir.

Üçüncü erek metninse ilk maddedeki 'temple' kelimesinden esinlendiği düşünülebilir. Nitekim son metnin çevirmeni Necla Aytür, çevirisine yazdığı ön sözde ana karakterin adının Temple olmasına dikkat çekerek şöyle bir tespitte bulunur:

Erdem ve güzelliğin timsali olan kadın kavramı, geleneksel Güney'de kutsallık mertebesindeyken, 'yeni' Güney’in kadını, adı “tapınak” anlamına gelen, ancak bu kavramdan çok uzak olan Temple'dır. Kalçasız, gögüussüz, aşırı boyalı, bakışları ile herkese meydan okuyan bir kızdır Temple. Çocuksu bir sorumsuzlukla hareket eder. Davranışları ile çevresindekilere zarar verdiğinin ya farkında değildir, ya da bunu umursamaz (Aytür, 2007: 7).

Her ne kadar çevirmen Aytür, Temple adının karşılığı olduğu için böyle bir ad seçtiğini ifade etmese de 'tapınak' kelimesinin hem romandaki karakterin adı, hem de 'sanctuary' kelimesinin Türkçe karşılığı olmasının, metnin adlandırmasında bir etken olduğu söylenebilir.

Erek metinlerden en dikkat çekeni, Lekeli Günler şeklindeki adlandırmayla ikinci çeviridir. 'Lekeli' (stained) kelimesi kaynak metinde tek bir yerde geçer. Romanda savcı, mahkeme salonunda suç delili olarak bir mısır koçanı gösterir ve tecavüze uğrayan Temple'a elindeki lekeli koçanın kendisine saldıran kişi tarafından tecavüz aracı olarak kullanıp kullanılmadığını sorar.

Bu noktada roman hakkında genel bir bilgi vermek gerekmektedir. Metin aslında bir cinayet ve tecavüz etrafında gelişen olaylar üzerine kurgulanmıştır. 17 yaşındaki üniversite öğrencisi Temple Drake, ailesinin sosyal konumu ve savcı olan babasının mesleği sayesinde imtiyazlı bir hayat sürmektedir. Bir gün Gowan Stevens'la randevusu sırasında yolu Old Frenchman Place adlı kaçak bir içki imalathanesine düşer. Mekânın sahibi olan Lee, karısı Ruby, ortağı Popeye ve çalışanı Tommy ile burada tanışır. Sarhoş olan Gowan bayılınca Temple, geceyi imalathanede geçirmek zorunda kalır. Sabah Popeye, Tommy'yi öldürür ve iktidarsız olduğu için bir mısır koçanıyla Temple'a tecavüz eder. Ardından Temple’’ kaçırıp Bayan Reba'nın genelevinde hapseder. Cinayet Lee'nin üstüne kalır. Olaylardan daha sonra haberi olan 
avukat Horace Benbow, Lee'nin savunmasını üstlenir. Horace'ın Lee ve diğerleriyle tanışması, yaşanan bu olayların öncesine dayanır. Eşini ve üvey kızını terk eden Horace, memleketine dönerken verdiği bir mola sırasında Popeye'la karşılaşır ve zorla imalathaneye götürülür. Lee, Horace'la burada tanışır ve ona yardımcı olur. Horace'ın eve dönüş yolculuğuna içki taşıyan kamyonlardan biriyle devam etmesini sağlar.

Davayı üstlendiğinde Horace'ın Temple'dan ve tecavüzden haberi yoktur. Olayın sadece bir cinayet davası olduğunu, esas suçlununsa Popeye olduğunu düşünür. Davayı kendisine daha önce iyiliği dokunan Lee'ye ve imalathanede tanıştığı Ruby'ye yardım etmek için üstlenir. Temple’a dair detayları gelişen olaylarla çok sonra öğrenir. Romanın sonunda bütün suçların cezası, masum olan Lee'ye kesilir. Mahkeme Lee’yi idama mahkûm eder, ancak Lee infazdan önce öfkeli kasabalılar tarafından linç edilir.

İdam kararı konusunda en somut gösterge olarak nitelendirilebilecek mısır koçanını tanımlayan 'lekeli' kelimesinin, kaynak metnin bu sahnesinden erek metnin adına taşınmış olması, çevirmenin neden böyle bir tercih yaptığı sorusunu akla getirmektedir. Diğer iki çeviride çeviri metne verilen adın kaynak metni çağrıştırabilmesi bir ihtimalken, buradaki çeviri kararının 'Lekeli Günler' adıyla metne başka bir boyut kazandırdığı düşünülebilir.

$\mathrm{Bu}$ çalışma kapsamında, öncelikle metin ve ad arasındaki ilişkiye ve adların verildikleri metinlerde üstlendikleri işlevlere kısaca değinilecektir. Ardından çeviri söz konusu olduğunda metni adlandırmanın beraberinde getirdiği sorunlar tartışmaya açllacaktır. Araştırma nesnesi olan romana verilen adın, kaynak metinde nasıl bir misyon üstlendiği ve bunun kaynak dizge bağlamında yarattığı tartışmalar gözden geçirilecek ve son olarak erek kültüre üç kez çevrilen bir kaynak metnin adının, her çeviride nasıl ve neden farklı yorumlandığı ele alınacaktır. Bu amaç doğrultusunda Türkçeye yapılan çevirilere verilen adların gerekçeleri irdelenecektir.

\section{Yan metin olarak metin adları ve metin ilişkisi}

Edebiyat eserlerinin adlandırılmasına ilişkin tartışmaların genellikle, metin ve ad arasındaki ilişkisellik, metinlere verilen adların üstlendikleri işlevler, metinlerin adlandırılma sürecinin nelerden etkilendiği ve adın metnin alımlanışına etkisi üzerinden gerçekleştirildiği görülmektedir. Bu tartışmalar arasında, "yan metin" (paratext) kavramıla tanınan edebiyat kuramcısı Genette'in tespitleri özellikle dikkat çeker. Genette "paratext" kavramını yazarın adı, metnin adı, ön söz, son söz, epigraf, dipnot, giriş ve çizimler gibi hem metin içi hem metin dışı görsel ve yazılı malzeme olarak tanımlar (1997: 1). Metnin birer ögesi şeklinde gördüğü bu parçalardan en çok metnin adını açıklamanın zor olduğunu ifade eder. Bu nedenle metin adlarının dikkatli bir çözümleme gerektirdiği vurgulanır (1997: 55).

Genette, metin adlarını kitabın türüyle ilgili olanlar (rhematic) ve kitabın içeriğiyle ilgili olanlar (thematic) şeklinde ikiye ayırır (1997: 79). Kitabın türüyle ilgili olanlar tek bir grup şeklinde incelenir ve metnin başına yazılan deneme, otobiyografi, şiir, ilahi, sözlük, fabl gibi bir ifade bu adlandırma şeklini örneklendirir (Genette, 1997: 86). Bu tür adlandırmalar metnin hangi türde yazıldığını ifade eder. Kitabın içeriğiyle ilgili olanlarsa kendi içinde dörde ayrılır: doğrudan metnin temel izleğini ifade eden adlar, aktarma yoluyla metnin temel izleğinin dışındaki bir şeye işaret eden adlar, mecazi anlamda kullanılan simgesel adlar ve metne zıt bir anlam barındıran adlar (Genette, 1997: 82-83). Bu çalışmanın araştırma nesnesi olan Sanctuary romanı Genette'e göre mecazi anlamda kullanılan simgesel adlar kategorisinde yer alır (1997: 82). Kategorilendirmede metinsel bir analizle detaylandırılmayan bu iddiaya, kaynak metnin adının kaynak dizgede yaratığı tartışmalar boyutunda tekrar değinilecektir. 
Genette metinlere verilen adları yukarıdaki şekilde iki gruba ayırmakla birlikte, bazı durumlarda metin adlarının her ikisinin de özelliklerini barındırabileceğini ifade eder (1997: 88). Örneğin John Locke’un An Essay Concerning Human Understanding adlı yapıtı hem metnin türüne hem de metnin konusuna işaret eder (Genette, 1997: 89). Farklı türde adlandırmaların aynı işlevleri yerine getirebileceğinin altını çizen Genette, metin adlarının dört işlevi olduğundan bahseder: tanımlayıcı (designating/identifying), betimleyici (descriptive), çağrışımsal (connotation) ve cezbedici (temptation)4 (1997: 93). Genette bu işlevlerden sadece birincisinin yani tamamlayıcılı̆̆ın bir zorunluluk olduğunu, ancak isteğe bağlı gibi görünseler de bu işlevin diğerlerinden ayrı düşünülemeyeceğini söyler (1997: 93).

Genette'in metin adlarına atfettiği zorunlu işleve dair benzer bir görüş "Title, Text, Meaning" adlı çalışmada Josep Besa tarafından da dile getirilir. Besa, metne verilen adın, işaret ettiği metni tanımlaması (designate) gerektiğini belirtir (1997: 324). Ancak buradaki tanımlamanın bir marka adı, etiket ya da özel isimden farklı olarak bir gösteren vazifesi üstlendiğinin ve adın metinle göstergesel bir ilişkisi olduğunun altını çizer (Besa, 1997: 325). Buradaki göstergesel ilişki aynı zamanda metnin temsiliyeti ile ilintilidir. Besa'ya göre adı olmayan bir metin dış dünyaya ulaşamaz, açık olamaz ve kendi içinde hapsolur (1997: 328).

Nitekim bir metnin adı, kişinin okuma kararında etkin bir rol oynayabilir. Okuma kararı almış birinin, metnin içine girmiş ve devam edip etmeme konusunda metinle baş başa kalmış olduğu söylenebilir. Ancak kişiyi metinle baş başa bırakmak, çoğu zaman metnin adına yüklenen bir sorumluluk olarak görülür ve bu sorumluluğu yerine getirebilmesi için metnin adının okuru ikna etmesi gerektiği iddia edilebilir; çünkü okur açısından bakıldığında ad, ait olduğu metni temsil eder. Dolayısıyla okur, ad ve metin arasında anlamlı ve bağlamsal bir ilişki olduğu düşünülebilir.

Bir metin okuru olarak araştırmacılar için de durum farklı değildir. Bir yan metin örneği olan metnin adının metinle olan ilişkisi sadece okur için değil araştırmacılar için de bir şeyler söyleyebilir. "What Texts Don't Tell: The Uses of Paratexts in Translation Research” başlıklı çalışmasında Şehnaz TahirGürçağlar, "metnin sessiz kaldığı noktalarda metin dışı ögeleri incelemenin bizlere çok ilginç bilgiler sunacağından” bahseder (2002: 59). Tahir-Gürçağlar’a göre, yayıncıların ve çevirmenlerin bakış açıları metin dışı ögelere yansıyabilir ve metin dışı ögelerdeki ipuçları araştırmacıları metni keşfetmeye teşvik edebilir (2002: 60). Nitekim bu çalışmayı teşvik eden de kaynak dizgede çalışmalara konu olan bir metin adının, erek kültürdeki çevirilerde üç farklı şekilde yorumlanmasıdır. Sanctuary adından Kutsal Siğınak, Lekeli Günler ve Tapınak adlarına giden süreci anlamak amaciyla metinlerin kendilerini keşfetme ihtiyacı duyulmuştur. Bu ihtiyaç doğrultusunda, metnin kendisini keşfetmeye geçmeden önce takip eden bölümde çeviribilim alanında çeviri metinlerin adlandırılması konusundaki tartışmalara değinilecektir.

\section{Metin adlarının çevirisi üzerine tartışmalar}

Metinlerin adlandırılmasına dair tartışmaların, çeviri eserler boyutunda tıpkı telif eserlerdeki gibi tanımlar, kategoriler ve işlevler üzerinden yürütüldüğü söylenebilir. Ancak çevirmenin sürece dâhil olmasıyla birlikte metin adlandırılmalarında bir de "sorumluluk" (reponsibility) kavramı tartışılmaya başlanmıştır. Literary Translation: A Practical Guide adlı yapıtında Clifford E. Landers, metni adlandırma konusunda çevirmenin sorumluluğunun yazarınkinden çok daha fazla olduğunu belirtir (2001: 142). Landers'a göre çeviride metin içi bir aksaklığın göz ardı edilmesi mümkünken, metnin adı kitabın bahsinin geçtiği her sefer göze batacak ve adın çeviri metne dair oluşturduğu izlenim daha da

$4 \quad$ Aksi belirtilmedikçe çeviriler tarafımızca yapılmıştır.

\footnotetext{
Adres | Adress 
pekişecektir (2001: 142). Landers, kendisine yüklenen fazla sorumluluğa rağmen, yine de çevirmenin yazara göre şanslı olduğunu, çünkü çevirmenin elinde en azından muhafaza edebileceği, değiştirebileceği ya da tamamen çıkarabileceği bir adın var olduğunu belirtir (2001: 143). Landers'ın çevirmenin metnin adıyla neler yapabileceğine dair söyledikleri, metinlerin adları nasıl çevrilebilir sorusuna öneri niteliğindedir. Soru aynı olmasına rağmen farklı araştırmacılar yaptıkları çalışmalarda farklı öneriler ortaya atmıştır.

Peter Newmark, A Textbook of Translation adlı kitabında bir çeviri birimi olarak değerlendirdiği metin adlarının çevirisinde, kaynak metnin adını referans alır. Newmark, içeriği yeterince ifade ediyorsa ve kısaysa metin adının aynen kalması gerektiğini savunur (1988: 56). Özgün adın anlatıcllı ve kısalık işlevlerini yerine getirmemesi durumunda ise çevirmen adı kısaltabilir, çeviri metnin adında temel izleği vurgulayabilir ya da daha dikkat çekici bir ad kullanabilir (1988: 56). Christiane Nord, Newmark'ın buradaki yaklaşımını geleneksel bakış açısı çerçevesinde sadakat anlayışının bir örneği olarak değerlendirir (1995: 268). "Text Functions in Translation: Texts and Headings as a Case in Point" adlı çalışmasında metin adlarını başlı başına bir metin türü olarak değerlendiren Nord, adların çevirisine işlev odaklı bir bakış açısıyla yaklaşır (1995: 262) ve metinlerin adlarına altı işlev atfeder: ayırt edici (distinctive), üstmetinsel (metatextual), ilişkisel (phatic), göndergesel (referential), anlamlayıcı (expressive) ve duyumsal (appellative) (1995: 264). Bu işlevlerden ilk üçü birincil, son üçüyse ikincildir (Nord, 1995: 265). Bu bakış açısına göre eğer bir metin adının çevirisi yapılacaksa önce kaynak kültürdeki işlevlerine bakılmalı, sonra bu işlevler erek kültürdeki bağlama aktarılmalıdır; ancak bu yaklaşım geleneksel bakış açısının sadakat anlayışıyla karıştııılmamalıdır. İşlev odaklı çeviri yaklaşımında, birincil işlevleri yerine getirmek için çevirmen, erek metnin adının, erek kültürün normlarına uyduğundan emin olmalıdır. İkincil işlevlerse sadece erek kültürün normları tarafından değil kaynak kültürün "maksadı" (intention) tarafından da belirlenir. Bir başka deyişle çevirmen, ereğin beklentileriyle kaynağın maksadı arasında uyum sağlayacak şekilde ikincil işlevleri belirlemelidir (Nord, 1995: 268).

Maurizio Viezzi ise Nord'un işlevsel yaklaşımından hareketle çeviride anlamın yeniden üretilmesinin bir öncelik olmadığını (2013: 379) ifade eder. "Titles and Translation" adlı çalışmasında, erek metnin diline çevrilen adların kaynak metnin adından çeşitli şekillerde farklılık gösterebileceğini belirtir. Viezzi’ye göre, çevrilen ad kaynak metindekinden farklı bir bakış açısını temel alabilir; kaynak metnin adına kıyasla daha açık bir şekilde ifade edilmiş olabilir; metin türüne dair bilgi verebilir; esere farklı bir yorum getirip metinlerarası bir göndermede bulunabilir ya da erek okuru cezbetmeyi amaçlayabilir (2013: 380$381)$.

Başka bir çalışmada çeviri metinlerin adları, İspanyolca ve İngilizce arasındaki dillerarası kurgu çevirileri bağlamında incelenmiştir. Michael S. Doyle, "Contemporary Spanish and Spanish American Fiction in English: Tropes of Fidelity in the Translation of Titles" adlı çalışmasında üç çeşit ad çevirisinden bahseder: birebir çeviri (literal translation), birebire yakın çeviri (near-literal translation) ve serbest çeviri (free translation) (1989: 42). Aynı çalışmada birebir çevirinin de kendi içinde üç alt kategoride ele alındığı görülür: metnin adının aynı zamanda metindeki bir karakterin adı olması ve özel isim olması sebebiyle çevrilmeyip aynen kullanılması; kaynak metnin adının kaynak kültürde kullanılan ancak kaynak dil için de yabancı bir kelime olması ve erek dile de aynen aktarılması; kaynak metnin kaynak dildeki adının çevrilmeyip erek dilde de kullanılması (Doyle, 1989: 42). Doyle, yapılan çalışmada incelenen çeviri adlarının en çok yakın çeviri kategorisinde örnekler sunduğu, serbest çeviri örneklerinde ise kaynak metnin adının ne olduğunu tahmin etmenin imkânsız hâle geldiği tespitinde bulunur (1989: 43-44). 
Görüldüğü üzere, çeviri metinlerin adlandırılmasına dair yapılan çalışmalar, çevirmenin neler yapabileceğini, çevrilen metin adının ne tür işlevler üstlenebileceğini, çeviri adın kaynak ya da erek vurgusuyla yorumlanıp farklı şekillerde ifade edilebileceğini ortaya koymaktadır. $\mathrm{Bu}$ çalışma kapsamındaysa incelenecek olan erek metinlerde, çevirmenlerin belirledikleri metin adlarının hangi vurguyla şekillendiği ve bunun metin içi çeviri kararlarına yansıyıp yansımadığı anlaşılmaya çalışlacaktır.

Araştırma nesnesini oluşturan çevirilerde kaynak metnin adı farklı yorumlanmış ve Kutsal Sı̆̆ınak, Lekeli Günler ve Tapınak adlarıyla üç erek metin ortaya çıkmıştır. Çeviri adlarındaki bu farklılığın temelinde, Maria Bobadilla-Pérez’in eser adlarına atfettiği özelliklerin yattığı söylenebilir. BobadillaPérez, "Relevance and Complexities of Translating Titles of Literary and Filmic Works" adlı çalışmasında eser adlarının, bütün anlatının en değişken ve en öznel parçası olduğundan bahseder (2007: 117). Eser adının değişken ve öznel olmasıysa telif metinde ve çeviride çeşitli sonuçları beraberinde getirir. Telife verilen ad, tıpkı karakterlere verilen özel adlar gibi bir edebî metne tüzel bir varlık kazandırır (Briffa \& Caruana, 2009: 3). Yaratıcılık gerektiği düşünülen çeviri söz konusu olduğunda ise adlar, çevirmenin beğenisine göre şekillenir (Briffa \& Caruana, 2009: 14). Eser adlarının değişken ve öznel olduğu görüşünden hareketle, öncelikle kaynak metin odaklı olarak addaki öznelliğin araştırma nesnesi olan romana, Amerikan edebiyatı bağlamında nasıl bir "tüzel kişilik" (particularized entity) (Krş. Briffa \& Caruana, 2009: 3) kazandırdığı anlaşılmaya çalışılacaktır. Ardından birbirinden değişik çeviri adlarının, çevirmenin beğenisine göre nasıl şekillendiği ve çevirmen beğenisinin, çeviri metnin adından, metin içi çeviri kararlarına nasıl yansıdığı irdelenecektir.

\section{Kaynak metnin adının kaynak metin bağlamında yarattığı tartışmalar}

Bu çalışmada ele alınan Sanctuary5 ${ }^{5}$ romanının adlandırılması üzerine kaynak dizgede yapılan iki araştırma özellikle dikkat çekmektedir. Bunlardan birincisi, Joseph R. Urgo tarafından kaleme alınan “Temple Drake's Truthful Perjury: Rethinking Faulkner's Sanctuary” (1983) adlı makaledir. Urgo, 'sanctuary' kelimesinin öylesine bir tercih olmadığını, hatta bunun "Faulkner'a ait bir kavramsallaştırma” olduğunu söyler (1983: 443). Urgo, bu iddiasını Faulkner'ın The Town (1957) romanında yer alan Gavin Stevens adında bir karakterin verdiği 'sanctuary' açıklamasına dayandırır:

\footnotetext{
"sanctuary"6, hayvanların ve insanların da, öyle kolayca ulaşamadıkları ancak hiddetli bir öfke ya da korku gibi dayanılmaz duygusal durumlardan geçerek edindikleri, bakış açısındaki mantıksallık [...] (Faulkner, 1957: 27)
}

Faulkner'ın romanları arasındaki metinlerarası ilişki düşünüldüğünde, Urgo'nun burada kurduğu metinlerarası ilişki anlamlı bir hâl alır. Faulkner'ın romanları Yoknapatawpha County denilen bir bölgede geçer. Eserlerinden birinde yer alan bir karakterin başka bir romanda tekrar okurun karşısına çıması olağandır. Benzer bir şekilde farklı romanlar da aynı izlek üzerinden tekrar kurgulanabilir. Urgo, burada kurduğu metinlerarası ilişkide bahsi geçen 'sanctuary' kavramını Temple karakteri üzerinden okur. Temple, Goodwin'lerin imalathanesinde kaldığı gece sonsuz bir korku, Bayan Reba'nın evinde kaldığı zamanlarsa sonsuz bir öfke yaşar ve sonunda Urgo'nun "the sanctuary of justice" diye nitelendirdiği mahkeme salonuna gelir (1983: 443-444). Urgo, Temple’’n verdiği ifadeyle adaletin sağlanmasına katkıda bulunmadığını, ancak süreçte kazandığı rasyonellikle daha ulvi bir gerçekliğe hizmet ettiğini iddia eder (1983: 444). Urgo'ya göre, Temple, tanıklığıyla her şeyin doğrudan sorumlusu

\footnotetext{
5 Çalışma kapsamında kaynak metin olarak nitelendirilen Sanctuary (1931) romanı, aslında Sanctuary: The Original Text adıyla 1981'de yayımlanan özgün metnin yeniden yazılmış hâlidir. Kaynak metnin aynı zamanda bir 'diliçi öz-çeviri' şeklinde ele alınabileceğine dair tartışma için Bkz. Canlı, 2018.

$6 \quad$ Sanctuary kelimesi burada özellikle çevrilmeden bırakılmıştır.
} 
olan Popeye'ı değil, Old Frenchman Place'e geldiği gece bir araba tahsis edip onu oradan uzaklaştırmayan ve liderlik ettiği çeteye karşı onu korumayan Lee'yi cezalandırır; çünkü Lee, ev sahibi olarak sorumluluklarını yerine getirmemiş ve işlerin kontrolden çıkmasına sebep olmuştur (1983: 444).

Kaynak dizgede adlandırma üzerinden yapılan ikinci araştırma ise Hal McDonald'a aittir: "Faulkner's Sanctuary" (1997). McDonald, romanın adının bir ironi barındırdığını ve bu ironinin de Old Frenchman Place'te farelerden korumak amacıyla Ruby'nin bebeğini içinde sakladığı kutu üzerinden okunabileceğini söyler (1997: 222). Ayrıca, araştırmada adlandırmadaki ironi, Lee Goodwin üzerinden de okunur. Ruby, yine koruma içgüdüsüyle hareket ederek bebeğinin babası Lee Goodwin'le başlangıçta iş birliği yapar ve Lee'nin Horace'a hiçbir şey anlatmaması konusundaki tembihine itaat eder. Lee hapishane hücresinde Popeye’a karşı tanıklık etmediği sürece güvende olduğunu, suçu işlemediği için zaten başına bir şey gelmeyeceğini, ancak Popeye’’ ihbar etmesi durumunda hücreden çıkar çıkmaz öldürüleceğini düşünür. Dışarıdaki tehlikelere karşı korunmaya çalışan bu iki karakter, gelişen olaylarla birlikte içeriden gelen tehlikelerle baş etmek zorunda kalır. Bebek farelerden korunur ama bu sefer de ateşlenip hastalanır ve Ruby bir doktor çağırmak zorunda kalır. Lee içinse Popeye bir tehlike arz etmez, çünkü zaten başka bir eyalette işlemediği bir suçtan tutuklanmıştır. Lee için asıl tehlike, içinde bulunduğu hücrenin temsil ettiği adalet sistemidir (McDonald, 1997: 223). Temple'ın ifadesinden sonra Lee suçlu bulunur ve mahkeme sonrası kasabalılar tarafından zorla hücresinden çıkarılıp linç edilir. Ne içinde saklandığı kutu bebeği ne de güvende olduğunu sandığı hapishane hücresi Leeyi korumayı başarmıştır. Her iki karakter için de tehlike, önlem alma ihtiyacı duydukları durumlardan değil, beklemedikleri olaylardan kaynaklanır. Güven içinde olduklarını ve yeterince önlem aldıklarını sanmalarına rağmen sonuç hiç de umdukları gibi olmaz.

McDonald'ın araştırmasında dikkat ettiği adlandırmadaki ironi Horace Benbow karakteri üzerinden de tartışılabilir. John T. Irwin "Horace Benbow and the Myth of Narcissa” (1992) adlı makalesinde Horace'ı "firari koca" şeklinde tanımlar (1992: 544). Karısı Belle için on yıldır her cuma istasyona gidip trenden aldığı karides kutularını eve taşıyan Horace, bir gün artık bu işi yapamayacă̆ına karar verir ve karısını terk eder. Niyeti, memleketi Jefforson'ın kendisine sunacağına inandığı güven duygusu içinde, annebabasından kalan evde, tek başına yaşamaktır. Ancak gelişen olaylar Horace'ın Jefforson'da huzur bulamayacağını gösterir. Kız kardeşi Narcissa, Lee'nin davasını üstlenmesinden son derece rahatsızdır. Ruby'ye yardım etmesinden hoşlanmaz, çünkü kardeşinin böyle bir kadınla yakınlaşma ihtimalinden çok korkar. Hatta, Ruby'nin Lee ile resmen evli olmadığını, ancak ondan çocuk sahibi olduğunu kasabalı diğer kadınlara anlatarak Ruby'yi kasabanın otelinden attırır. Narcissa, Horace'a davayı kaybettirmeyi aklına koyar. Horace'ın haber kaynağının Senatör Snopes olduğunu anlayınca Bölge Savcısı'nı durumdan haberdar eder. Savcı, tıpkı Horace gibi Temple'ın yerini Senatör Snopes'tan öğrenir ve Temple mahkeme günü Lee'yi suçlayan bir ifade vermek için tanıklığa çağrılır. Horace davayı kaybeder ve karısına geri döner. Memleketinde huzur ve güven içinde yaşayacağını sanan Horace için aslında olaylar tam bir hayal kırıklığıyla sonuçlanır.

Toparlamak gerekirse, ilk araştırmada "Faulkner'a ait bir kavramsallaştırma” (Urgo, 1983: 443) şeklinde açıklanan metnin adı, metinlerarası bir göndermeyle anlamlandırılmıştır. Aynı adlandırma, ikinci araştırmada farklı bir okumayla karşımıza çıkmaktadır. McDonald'ın iddia ettiği ironi (1997: 222), sözlük anlamı düşünüldüğünde güven, korunma gibi kavramları çağrıştıran bir ada rağmen, metnin kendisinin bu kavramlardan yoksun oluşuyla açıklanabilir. Hatta André Malraux, Sanctuary romanının Fransızca çevirisine yazdığı ön sözde, olay örgüsünün, uyumsuz, kudretli, zalim bir boyutta kişisel ve bazen kaba bir dünya yarattığını ifade eder (1952: 92). McDonald'ın ilgili bakış açısı ve Malraux'nun ilgili değerlendirmesi göz önünde bulundurulduğunda, metinle ad arasında aslında bir zitlık olduğu 
söylenebilir. Buradan hareketle, Genette'in "mecazi anlamda kullanılan simgesel adlar" kategorisine yerleştirdiği Sanctuary romanı (1997: 82) başka bir kategori bağlamında da değerlendirilebilir. Metnin içeriğinin adına zıt bir şekilde kurgulandığg düşünüldüğünden, Sanctury'nin Genette tarafından ortaya atılan "metne zit bir anlam barındıran adlar" (1997: 83) kategorisine dâhil edilmesi söz konusu olabilir.

Görüldügü üzere inceleme nesnesi olan kaynak metne verilen ad, farklı okumalarla yorumlanmıştır. Kaynak metnin adının barındırdığı yorumsal anlam çeşitliliğinin, çeviri söz konusu olduğunda nasıl ele alınabileceği takip eden bölümde çeviri kararları üzerinden okunmaya çalışılacaktır.

\section{Erek metinlerin adlarının metin içi çeviri kararlarına yansımaları}

Daha önce de belirtildiği üzere çalışmanın araştırma nesnesi oluşturan Sanctuary romanının kaynak dizgede farklı bakış açlarıyla tartışılan adı, Türkçeye sırayla Kutsal Siğınak (1961), Lekeli Günler (1967) ve Tapınak (2007) şeklinde çevrilmiştir. Çeviri adlarına bakıldığında, birinci ve üçüncü erek metinde 'sanctuary' kelimesinin olası sözlük anlamları üzerinden çevrildiği söylenebilir. Burada dikkat çeken, ikinci çevirinin adıdır. Diğer iki çeviriye kıyasla tamamen farklı bir yorum katılan ikinci çevirinin adı, kaynak metnin adının ne olduğunu tahmin etmeyi imkânsız hâle getirmektedir. Metnin adına getirilen bu farklı yorumun, metin içi çeviri kararları için de söz konusu olabileceği düşünüldüğünden, bu bölümde çeviri metinlerden farklı örnekler sunulacak ve metinlere verilen adlar gerekçelendirilmeye çalışlacaktır.

\section{Örnek 1:}

KM: There are so many of them (Faulkner, 1931: 62).

EM1: Amma da insan bolluğu var burada (Faulkner (Çev. Gürol), 1961: 36).

EM2: Burada o kadar çok insan var ki (Faulkner (Çev. Sunar), 1967: 55).

EM3: O kadar çok adam var ki (Faulkner (Çev. Aytür), 2007: 48).

Old Frenchman Place’te kaldığı gece, Ruby ile mutfakta konuşurken söylediği bu cümle Temple’ın sakin ve iyimser kalmak adına sarf ettiği çabanın göstergesi niteliğinde ele alınabilir. Temple, evdeki adamların kendisine zarar verebileceğinin farkındadır, ancak sayıca çok olmalarını bir avantaj gibi görür. Erkek arkadaşı Gowan, imalathanenin sahibi Lee Goodwin ve iş ortakları Popeye, Tommy, Van ile artan erkek sayısı Temple'da bir güven hissi yaratır. Kendini sakinleştirmek adına, "There are so many of them" (Faulkner, 1931: 62), [...] "But maybe, with so many of them..." (Faulkner, 1931: 62) diyerek mevcut erkek grubunun bireysel bir saldırının önüne geçeceğine inanır.

Kaynak metnin adını Temple karakteri üzerinden okuyan ve 'sanctuary'yi Faulkner'a ait bir kavramsallaştırma olarak gören Urgo’ya göre, bu inancın altında aslında Temple’ın çaresizce ihtiyaç duyduğu ve Old Frenchman Place’te bile var olduğuna inandığı "kamu himayesi” (civil protection) (1983: 438) yatar. Urgo, kamu himayesini, uygar toplumun yarattı̆̆ "kutsanmış kadınlık miti" (the myth of sanctified womanhood) (1983: 437), başka bir deyişle geleneksel ideolojinin kadını eril dünyadan ayırıp "kutsanmış bir dünyaya" (sactified world) hapsedişi (1983: 437) şeklinde okur. Bütün bu mitler Old Frenchman Place’te geçerliliğini yitirir. Dışarıdaki dünyada Temple’a bir hanımefendi gibi

Metin içi çeviri kararlarının yeniden çeviri bağlamında ele alındığı ve daha fazla örneğin sunulduğu bir tartışma için Bkz. Canlı \& Karadağ, 2018. 
davranan Gowan, çok içer ve bayılır, Temple'ı imalathanedeki yabancılarla yalnız bırakır. Lee ise ne mekân sahibi olarak sorumluluğunu yerine getirir ne de diğerleri üzerindeki otoritesini kullanarak Temple’’ korumaya çalışır. Temple, çaresizce ihtiyaç duyduğu bir anda uygar dünyada sahip olduğu bütün ayrıcalıklardan ve bir kadın olarak kanıksadığı korunma kalkanından mahrum kalır ve tecavüze uğrar. Uygar dünyanın sunduğu güvenlik hissi, Temple için sadece bir yanılgıdan ibarettir.

Örnekte verilen ve kaynak metinde geçen 'them' zamiri tek başına cinsiyet belirtmeyen bir ifade olsa da bağlam içinde evdeki erkeklerden bahsetmek için kullanılmıştır. Ancak birinci ve ikinci erek metne bakıldığında evdeki erkekleri işaret eden 'them' zamirinin çevirisinde genellemeye gidildiği ve 'insan' denilerek çevrildiği görülmektedir. Üçüncü erek metin, kaynak metinde kullanılan zamire atfedilen cinsiyetin farkında olarak bir çeviri kararı almış ve 'adam' ifadesini kullanmıştır. Erkek cinsiyetinin kastedildiği, ancak ilk iki erek metnin birinci örnektekine benzer şekilde genellemeye gittiği bir başka çeviri kararı ikinci örnekte de görülmektedir.

\section{Örnek 2:}

KM: Boys will be boys, wont they? (Faulkner, 1931: 248).

EM1: İnsanlar hep bir, değil mi? (Faulkner (Çev. Gürol), 1961: 129).

EM2: İnsanlar her yerde insandır, değil mi? (Faulkner (Çev. Sunar), 1967: 187).

EM3: Erkek ne de olsa erkektir, deel mi? (Faulkner (Çev. Aytür), 2007: 163).

Bu örnekteki cümle Senatör Snopes'a aittir. Horace, Senatör Snopes'tan Temple'ın yerini öğrendikten sonra onu ziyarete gider. Snopes, Bayan Reba'nın genelevine girerken yolunu kestiği Horace'a, onu bu civarda gördüğünü kimseye söylemeyeceğine dair söz verir. Horace'ın geneleve geliş sebebini bildiği hâlde, sanki Horace mekânın müşterisiymiş gibi bir imada bulunur. Evli, ancak karısından ayrı bir erkeğin belli ihtiyaçlarının olduğundan bahseder. Aslında kendisi böyle yerleri ziyaret etme alışkanlığı olan bir adamdır. Nitekim örnekteki cümleyi de erkeklerin böyle alışkanlıklarının olmasının çok normal olduğunu düşünerek söyler. Horace, Snopes'u ciddiye almayı Temple’’ görmek için eve girince de siyahi kadınların çalıştığı başka bir genelevin adresinin yazılı olduğu bir kâğıdı evin hizmetçisiyle Horace'a gönderir.

Temple geneleve hapsedilince, ona ne olduğundan haberi olmadığı hâlde ailesi, üniversitede çıkan dedikoduları yalanlamak ve aile onurunu korumak için yerel gazetede bir metin yayımlatır. Dedikodulara göre Temple biriyle kaçmış, gazetedeki habere göre ise kuzeydeki bir akrabanın yanına yerleştirilmiştir. Temple'ın ortadan kaybolması, geneleve hapsedildiği bilinmediği hâlde, ailesi için bir sosyal felaket ihtimali barındırır. İleriki bölümlerde bir genelevde hapsedildiği ortaya çıtığında bile bu durum saklanır, böyle bir şey hiç yaşanmamış gibi davranılır. Kadınlar için bir felaket bölgesiyken, metinde çizilen erkek imgesi için geneleve gitmek sıradan bir alışkanlık olabilmektedir.

Kaynak metinde ilk iki örnekte altı çizilen toplumsal cinsiyet meselesi, ilk iki erek metindeki çeviri kararlarıyla görmezden gelinmiştir. İlk iki erek metin, burada bahsi geçen erkek cinsiyetini, zamir kullanımı söz konusu olmadığı ve kaynak metinde yeterince açık ifade edildiği hâlde, tıpkı ilk örnekteki gibi, 'insanlar' diyerek çevirmeyi tercih etmiştir. Bu nedenle aslında toplumsal cinsiyet açısından çok önemli bir mesele yok sayılmıştır. Kaynak metinde cinsellik söz konusu olduğunda erkekler toplumsal açıdan ayrıcalıklıdır. Ancak çeviride yapılan genellemelerle, bu ayrıcalığın üstü örtülmüştür. 
Üçüncü çeviride ise örnekte bahsi geçenin erkek imgesi olduğunu belirten bir karar alınmıştır. Kaynak metindeki toplumsal cinsiyet konusunun, çeviri metinlerde başka şekillerde ele alındığı, devam eden örneklerle de gösterilmeye çalışlacaktır.

\section{Örnek 3:}

KM: 'It better not born at all,' she said. 'None of them had.' (Faulkner, 1931: 253).

EM1: 'Doğmasa daha iyi olurdu,' dedi. 'Hiçbiri doğmasaydı keşke.' (Faulkner (Çev. Gürol), 1961: 132).

EM2: 'Keşke hiç doğmasalardı şu piçler.' (Faulkner (Çev. Sunar), 1967: 191).

EM3: 'Keşke o çocuk hiç doğmasaydı,' dedi. 'Hiçbiri doğmasa.' (Faulkner (Çev. Aytür), 2007: 166).

Verilen örnekte Ruby'nin bebeği ve benzer durumdaki çocukların bahsi geçer. Temple'la görüşebilmek için Bayan Reba'dan izin almaya çalışan Horace, durumun ciddiyetini netleştirmek için Bayan Reba'ya Ruby ve bebeğinden bahseder. Temple, Lee lehine şahitlik etmezse, Ruby'nin tekrar sokaklara düşeceğini ve çocuğun akıbetini ise tahmin bile edemediğini söyler. Bayan Reba'ya çocuğu olup olmadığını sorduğundaysa kadının başka bir eyaletteki dört çocuğun bakımını üstlendiğini öğrenir. Bayan Reba örnekteki cümlede 'it' diyerek Ruby'nin bebeğini, 'none of them' diyerek zor şartlar altında yaşamak zorunda kalan çocukları kasteder ve hiçbirinin dünyaya gelmemiş olmasını dilediğini söyler.

Birinci ve üçüncü erek metinde Bayan Reba'nın çocuklar için temennisi aktarılırken, ikinci erek metne 'piç' kelimesinin eklendiği görülmektedir. İkinci erek metnin çevirisinde kullanılan bu kelime, Türkçe Sözlük'te evlilik bağı olmayan insanların sahip olduğu ya da babası bilinmeyen çocuk şeklinde açıklanmaktadır (2011: 1923). Kaynak metindeki kurguda Ruby'nin bebeği evlilik dışı olsa da metin içinde 'piç' kelimesinin, bu şekilde kullanılmadı̆̆ örnekte bir ekleme yaparak hem Ruby'nin bebeğini hem de onunla aynı durumda olan çocukları işaret edecek şekilde 'piç' kelimesini erek metne eklemiştir.

\section{Örnek 4:}

KM: That was the only part of the whole experience which appeared to have left any impression on her at all: the night which she had spent in comparative inviolation. (Faulkner, 1931: 258).

EM1: Olayın yalnızca bu bölümü sanki, etkilemişti onu, kimsenin doğrudan doğruya saldırıya uğramadan geçirdiği gece. (Faulkner (Çev. Gürol), 1961: 134).

EM2: Kimsenin kendisine tecavüz etmediği o geceden kalan izler sadece bunlardı sanki. (Faulkner (Çev. Sunar), 1967: 194).

EM3: Başından geçen şeylerden yalnız bu bölümü onun üstünde bir iz bırakmış gibiydi: Göreceli olarak rahat bırakıldı ğı geceydi bu. (Faulkner (Çev. Aytür), 2007: 169).

Örnekteki ifade Temple’ın Horace’ta bıraktığı izlenimi ifade eder. Bayan Reba'dan izin alıp Temple'ın odasına çıkan Horace, o gece yaşananları ve katilin kim olduğunu öğrenmek ister. Temple bir türlü zihnini toparlayıp yaşananları sırayla anlatamaz. Konuşma sırasında daldan dala atlar, başka şeylerden 
bahseder. Temple'ın zihninde yer eden en önemli şey, o gece Ruby'nin onu alıp ahıra götürmesi ve saklamasıdır. Bu sayede gece boyunca güven içinde kalmıştır. Popeye'ın ertesi sabah kendisine saldırdığını söylemekten kaçınır.

Kaynak metin her ne kadar bir tecavüz etrafında şekillense de 'tecavüz' kelimesi metinde hiç kullanılmamıştır. Metne genel olarak örtük bir anlatım hâkimdir. Temple yaşananları ilk ağızdan Horace'a anlatırken bile uğradığı saldırının ayrıntılarına girilmez. Birinci ve üçüncü erek metin, kaynak metinde benimsenen bu örtük anlatım konusunda daha dikkatli davranmış, tecavüz kelimesi kullanılmamıştır. İkinci erek metinse tecavüz kelimesini doğrudan kullanmayı tercih etmiştir. İkinci erek metnin çeviri kararlarında bu örnektekine benzer şekilde açımlamaya gittiği, takip eden örneklerde de görülmektedir.

\section{Örnek 5:}

KM: There was a girl went abroad one summer that told me about a kind of iron belt in a museum a king or something used to lock the queen up in when he had to go away. (Faulkner, 1931: 261).

EM1: Geçen yaz Avrupa'ya giden bir kız söylemişti, müzelerin birinde gördüğü demir bir kemerden söz etmişti, kral mı ne, biri yolculuğa çıkınca kraliçesi o kemeri takarmış. (Faulkner (Çev. Gürol), 1961: 135).

EM2: Geçen yaz bir arkadaşım Avrupa'ya gitmişti. O anlatmıştı. Bir müzede demirden bir bekaret kemeri görmüş. Kral yahut bir başka erkek uzağa gideceği zaman karısına bu kemeri takarmış. (Faulkner (Çev. Sunar), 1967: 196).

EM3: Yazın yurtdışına giden bir kız vardı, o anlatmıştı, müzede demirden bir çeşit kemer varmış, bir memleketin kralı bir yere gitmesi gerekince kraliçeye bunu takar, kilitlermiş. (Faulkner (Çev. Aytür), 2007: 171).

Örnekte konuşan kişi Temple'dır. Temple, Horace'a olayları anlatırken, Popeye ona saldırdığında çok korktuğundan ve kendini bir şekilde kilitlemek istediğinden bahseder. Bu sırada da aklına bir arkadaşının Fransa'da görüp bahsettiği demir kemer gelir. Kemerin ne işe yaradığını bilen Temple, o sırada böyle bir kemer takmış olmayı aklından geçirdiğini anlatır.

Birinci ve üçüncü erek metin, bahsi geçen kemerin demirden yapıldığını ifade ederken, ikinci erek metin 'bekâret' kelimesini kullanmıştır. Erek dizgede 'bekâret' kelimesi kadının cinsiyetine özgü bir şekilde, kadının namusundan bahsetmek için kullanılır. Türkçe Sözlük'te bekâret kelimesinin karşılı̆̆ı olarak verilen ilk madde, "kızlık" şeklinde ifade edilmiştir (2011: 295). Ayrıca, bu ilk madde "Hangi erkek aşk yapmadan evlendiği kızdan tam bir bekâret beklemez?” şeklinde örneklendirilmiştir. Kaynak metne bakıldığında bekâret kelimesinin İngilizce karşılı̆̆ı olan "virgin" kelimesinin kullanılmadığı tespit edilmiştir. İkinci erek metnin çevirmeni bu örnekteki çeviri kararıyla kültürel açımlama yapmayı tercih etmiştir. Yapılan bu kültürel açımlamadaki ima, takip eden örnekte daha da açık ifade edilmiştir.

\section{Örnek 6:}

KM: 'Served him right.' The driver said. 'We got to protect our girls. Might need them ourselves.' (Faulkner, 1931: 357). 
EM1: ‘'̇yi oldu’ dedi şoför. 'Kızlarımızı korumalıyız, kendimize gerekir.' (Faulkner (Çev. Gürol), 1961: 185).

EM2: 'Hak etmişti' dedi şoför. 'Kızlarımızın namusunu korumamız gerek. Bizim onlara ihtiyacımız olacak.' (Faulkner (Çev. Sunar), 1967: 270).

EM3: 'Layı̆̆ını bulmuş. Kızlarımızı korumalıyız. Bize de gerekebilir onlar.' (Faulkner (Çev. Aytür), 2007: 231).

Romanın sonunda davayı kaybedip yenilgiyi kabullenen Horace, karısına dönmeye karar verir. Horace’ı evine geri götüren şoför, Lee'nin yargılamada suçlu bulunduğunu ve kasabalılar tarafından linç edildiğini duymuştur ve bunun hak edilmiş bir ceza olduğuna inanmaktadır. Örnekteki cümle, Lee'nin linç edilmesinin haklılığını savunan şoföre aittir.

Birinci ve üçüncü erek metinler benzer bir çeviri kararı alırken, ikinci erek metin önceki örnekte ima ettiği namus kavramını, bu örnekteki çeviri kararına alenen eklemiştir. İkinci çeviride kullanılan 'namus' kelimesi daha önceki örneklerde kullanılan 'bekâret' ve 'piç' kelimeleri gibi kadın cinsiyeti üzerinden tanımlanan çağrışımlar barındırır8. Metinde "namuslu olması gereken", "bekâreti sorgulanan" ve "resmen evli olmadığı bir adamdan çocuk dünyaya getirerek eleştirilen” kadın cinsiyetidir.

\section{Sonuç gözlemleri}

Genette'in de belirttiği üzere metin adları, yüzyllar boyunca metinde kendine ait bir yer edinememiş ve çoğu zaman sadece sözlü aktarımla kulaktan kulağa dolaşarak var olmayı başarmıştır (1997: 64). Günümüzde bu adlandırmalar metnin bir parçası olarak kanıksanmış, hatta okur için her metinde yeni bir okuma macerasına kapı aralamıştır. Aralanan bu kapının, çoğu zaman beklentileri de beraberinde getirdiği, metnin okur tarafından alımlanışında ve yorumlanmasında önemli bir rol oynadığı söylenebilir.

Çeviri söz konusu olduğundaysa tıpkı metin içi kararlar gibi, metnin adı da çok farklı şekilde yorumlanabilmektedir. Nitekim Faulkner'n romanı Sanctuary özelinde de böyle bir yorum farkı söz konusu olmuştur. Bu çalışmada Türkçeye üç kez farklı adlarla çevrilen bu roman özelinde ad, metin ve çeviri ilişkiselliği irdelenmiştir.

Ele alınan erek metinlerden birincisinde ve üçüncüsünde, ilk bakışta kaynak metnin adının sözlük anlamı üzerinden çevrildiği söylenebilir. Her iki metnin çeviri kararlarına bakıldığında, ilk iki örnek dışında, benzer bir yaklaşım benimsendiği ve çeviride birbirine yakın ifadeler kullanıldığı iddia edilebilir. İlk iki örnekte, birinci erek metinde ikinci erek metne yakın çeviri kararları alındığı ve kaynaktaki erkek imgesinin erek metne taşınmadığı görülmektedir. Ancak takip eden örneklerde, daha kaynak metin odaklı bir çeviri yaklaşımının benimsendiği tespit edilmiştir. Kaynak metin odaklılık konusunda ilk çevirmenin herhangi bir açıklaması bulunmamaktadır.

Üçüncü erek metnin çevirmeni Necla Aytür ise, kaynak odaklılık üzerine görüşlerini de dile getirdiği bir kitap kaleme almıştır. Denemelerden oluşan Kitaplar Arasında (2010) adlı yapıtının "Çeviri Üzerine Düşünceler" başlıklı bölümünde Aytür, çeviriye dair fikirlerini paylaşmıştır. Bu yazıda, çeviride yazarın biçemine önem verilmesi gerektiğinden, özgün metnin zenginliği yanında çeviri metnin

8 Türkiye'de kadı̈ öznelliğinin inşası ve yeniden üretimi konusunda "namus" kavramının dil, hukuk, cinsiyet ve çeviri ilişkiselliğinde incelendiği bir tartışma için Bkz. Öner, 2018. 
yoksunluğundan, ölümcül kayıplar vermeden çevirinin nasıl yapılacağından ve birbirinden çok ayrı iki dil arasında tam bir çevirinin mümkün olamayacağından bahsedilmiştir (2010: 161-172). Bu konulardaki vurgu noktaları dikkate alındığında çevirmenin kaynak odaklı bir yaklaşım benimsemesinin yadırgatıcı olmadığı açıktır. Dolayısıyla hem çeviriye dair görüşleri hem de metin içi çeviri kararları düşünüldüğünde, Aytür’ün metnin adında kelime anlamını önceleyen bir çeviri tercihi yapmış olması anlaşılır bir durumdur.

İkinci çevirinin adını anlamlandırmak içinse çeviri kararlarında görülen farklılıklara dikkat çekmek gerekir. Çevirmen, özellikle erkek imgesinden bahsedilen ilk iki örnekte genellemeye gitmiştir. Kaynak metinde anlatılan erkek imgesi, ilk örnekte ima edildiği üzere kadınlar için tehlike arz edebilir. İkinci örnekte ise, cinselliğin erkek için bir ihtiyaç olduğu görüşüyle erkeklerin genelev ziyaretleri normalleştirilmiştir. İkinci metnin çevirmeni ilk iki örnekte yaptığı genellemelerle kaynak metinde çizilen erkek imgesini erek metne taşımamıştır. Yapılan genellemelerde 'erkek' yerine 'insan' ifadesinin kullanılmasıyla, erkeklerin temize çıktığı, tecavüz kültürünün yok sayıldığı ve kaynak metindeki toplumsal cinsiyet vurgusunun kaybolduğu söylenebilir. Takip eden örneklerde ise çevirmen yaptığı eklemelerle metne farklı bir yorum getirmiştir. Kaynak metinde geçmediği hâlde üçüncü örnekte 'piç', dördüncü örnekte 'tecavüz', beşinci örnekte 'bekâret', altıncı örnekte 'namus' kelimelerini metne eklemiştir. Çevirmene özgü bu yorumsal tercihler, metnin adlandırılması söz konusu olduğunda da devam etmiştir. Türkçe Sözlük'te 'leke' kelimesi için verilen açıklamalara bakıldığında maddelerden biri dikkat çeker: "yüz kızartacak durum, namussuzluk, kara, şaibe" (2011: 1581). Aynı kaynakta 'lekeli' kelimesi için verilen açıklamalardan biri ise "kötü tanınmış, lekelenmiş" (2011: 1581) şeklindedir. Tanımlardan hareketle, çevirmenin cinsiyetçi bir okuma yaptığı söylenebilir. Çevirmen hem metin içi kararlarında hem de metni adlandırırken kaynak metni cinsiyetçi bir yaklaşımla yorumlamıştır. Çevirmenin metne gösterdiği bu cinsiyetçi yaklaşım, metin içi dil kullanımında ve metnin adlandırılmasında belirgin bir hal almıştır. Yapılan incelemede elde edilen bulgular, Viezzi'nin adlandırmaların masum olmadığı (2013: 383) tespitini haklı kılar niteliktedir.

\section{Kaynakça}

Aytür, Necla. (2010). Kitaplar Arasında. İstanbul: Yapı Kredi Yayınları.

Besa, Josep. (1997). Title, Text, Meaning. Textual Practice, Cilt 11, Sayı 2, 323-330. doi: 10.1080/09502369708582281.

Bobadilla-Pérez, Maria. (2007). Relevance and Complexities of Translating Titles of Literary and Filmic Works. Filología y Didáctica de la Lengua, (9), 117-124.

Briffa, Charles \& Rose Marie Caruana. (2009). Stylistic Creativity When Translating Titles. The Poetics and Linguistics Association (PALA) 2009 Conference, Roosevelt Academy, Middleburg: The Netherlands. $\quad$ Erişim $11 \quad$ Ocak https://www.pala.ac.uk/uploads/2/5/1/o/25105678/briffa2009.pdf.

Brown, Gillian \& George Yule. (1983). Discourse Analysis. Cambridge: Cambridge University Press.

Canl, Gülsüm \& Ayșe Banu Karadağ. (2018). Retranslations of Faulkner's Sanctuary in Turkish Literature. Advances in Language and Literary Studies, Cilt 9, Sayl 3, 173-184. doi: 10.7575/aiac.alls.v.9n.3p.173.

Canl, Gülsüm. (2018). Relocating Self-Translation from the Interlingual to Intralingual: Faulkner as a Self-Translauthor. TransLogos Translation Studies Journal, Cilt 1, Sayl 1, 41-63.

Doyle, Michael S.. (1989). Contemporary Spanish and Spanish American Fiction in English: Tropes of Fidelity in the Translation of Titles. Translation Review, Cilt 30, Sayı 1, 41-46. doi: 10.1080/07374836.1989.10523464.

Faulkner, William. (1931). Sanctuary. New York: Random House. 
Faulkner, William. (1961). Kutsal Sığınak. Çev. Ender Gürol. İstanbul: Cem Yayınları.

Faulkner, William. (1967). Lekeli Günler. Çev. Özay Sunar. İstanbul: Altın Kitaplar Yayınevi.

Faulkner, William. (2007). Tapınak. Çev. Necla Aytür. İstanbul: Yapı Kredi Yayınları.

Genette, Gérard. (1997). Paratexts: Thresholds of Interpretation. Cambridge: Cambridge University Press.

Hornby, Albery Sydney. (1995). Oxford Advanced Learner's Dictionary of Current English. Oxford: Oxford University Press.

Irwin, John T.. (1992). Horace Benbow and the Myth of Narcissa. American Literature, Cilt 64, Sayı 3, 543-566.

Landers, Clifford E.. (2001). Literary Translation: A Practical Guide. Clevedon: Multilingual Matters.

Malraux, André. (1952). A Preface for Faulkner's Sanctuary. Yale French Studies, (10), 92-94.

McDonald, Hal. (1997). Faulkner's Sanctuary. The Explicator, Cilt 55, Sayl 4, 222-223.

Newmark, Peter. (1988). A Textbook of Translation. New York: Prentice Hall.

Nord, Christiane. (1995). Text Functions in Translation: Texts and Headings as a Case in Point. Target, Cilt 7, Sayl 2, 261-284. doi: 10.1075/target.7.2.05nor.

Öner, Senem. (2018). Namus: “Çeviri” Olarak Kadın. Trakya Üniversitesi Edebiyat Fakültesi Dergisi, Cilt 8, Sayl 15, 110-118.

Tahir-Gürçağlar, Şehnaz. (2002). What Texts Don't Tell: The Uses of Paratexts in Translation Research. Crosscultural Transgressions: Research Models in Translation Studies, Ed. Theo Hermans, 446o. London/New York: Routledge.

Türk Dil Kurumu. (2011). Türkçe Sözlük (11. Baskı). Ankara: Türk Dil Kurumu Yayınları.

Urgo, Joseph R.. (1983). Temple Drake's Truthful Perjury: Rethinking Faulkner's Sanctuary. American Literature, Cilt 55, Sayl 3, 435-444.

Viezzi, Maurizio. (2013). Titles and Translation. Point of View as Challenge, Perspektivität als Herausforderung, Ed. Eronen, M. \& M. Rodi-Risberg, VAKKI-Symposium XXXIII, 374-384. Vaasa: Finland. 